\title{
RECONSTRUCTION OF CHARACTER VALUES BASED ON MANGGARAIAN CULTURE
}

\author{
Yuliana Wahyu ${ }^{1}$, dan Ambros Leonangung Edu ${ }^{2}$ \\ ${ }^{I}$ Program Studi PGSD STKIP Santo Paulus Ruteng, Indonesia \\ ${ }^{2}$ Program Studi PGSD STKIP Santo Paulus Ruteng, Indonesia
}

\begin{abstract}
This study aims at exploring and finding the character values in penti ceremony, Manggarai. Penti means the harvest thanksgiving ceremony of the Manggarai people. Penti is a sign of gratitude to God the Creator (Mori Jari Dedek) and to the ancestral spirits over all the crops. This research is conducted in East Manggarai district, NTT Province. There are several stages of ceremony penti, they are teinghang, barong lodok, barong wae, libur kilo, dan tiba meka landang. Each of these preparations with ritualistic rituals have their oun meanings. Technique of collecting data is done through interview and literature study. The research shows that penti emphasizes customs, imitation, exemplary, command, reward, and authority in character formation. Character formation is inseparable from the cultural environment in which children grow and develop.
\end{abstract}

\section{Keywords: Character Values, Penti Ceremony, Manggarai}

\section{INTRODUCTION}

\subsection{Background Problems}

One source of character formation is local cultural values. So far, local culture has been isolated into the periphery due to the effects of globalization that uphold Western civilizations. Along with the rise of grassroots movements as the antithesis to globalization, where locality is now more emphasized than globalism, the learning context is shifting from the domain of macro theories to the more practical and implicative local domains. In Manggarai, Nusa Tenggara Timur Province, there are many local assets that have been buried, and now education practitioners continue to explore more deeply about the local wealth as a source of value for the personal formation of learners of character. Among the rows of cultural assets, one of them is a pent ceremony. Penti is a thanksgiving ceremony. This ceremony is firmly attached to the life of the Manggarai people because the majority of Manggarai people (70\%) are farmers. The ceremony is always celebrated every year and successfully unites every people from various backgrounds. Based on this brief description can be seen how the ceremony penti is a cultural and aesthetic expression of the character of Manggarai people who packed in a cultural ceremony. To further examine the values of 
characters in the distribution of ceremonial lodges, the research team tried to make a study entitled "Reconstructive Values of Character in Manggarai Culture in NTT Province".

\subsection{Problem Formulation}

The problem becames the basis of this writing is: what are the character values in penti ceremony in Manggarai, NTT Province?

\subsection{Purpose of the Study}

This study aims at finding the character values in penti ceremony in Manggarai, NTT Province.

\subsection{Benefit of Study}

Firstly, the Manggarai teritory, which is currently divided into three districts (East Manggarai, Manggarai and West Manggarai) must maintain the unity of penti ceremony unaffected by geographical sectoral interpretations and segregations that may obscure the original Manggarai heritage. Second, the research team try to explore more about the values of the characters in penti ceremony.

\section{Literature Review}

\subsection{Character Values}

Professional education process will certainly form the character of the students. The characters that are meant are honesty, integrity, justice, courage, virtue (Fajarini, 2014: 6). The ASPEN Declaration presents six main ethical values that form the basis of character building: (1) trustworthy which includes honesty and integrity, (2) treating others with respect, (3) responsible, (4) fair, (5) affection, and (6) good citizens (Mundiri, 2012: 42). Strengthening the character is not only the role of the school but also the family, religion, culture, and community or environment. Indonesia has a diverse cultural diversity. In that culture there is a dimension of philosophy, psychology, sociology, and religion that contains values of character that can be developed along with character education at schools. This paper raises the local wisdom of Manggarai region, NTT Province, about penti as a cultural asset forming character values. There are some stages of the rituals performed.

\subsection{The Nature of Penti Ceremony}

\subsubsection{Meaning and Purpose of Penti}

Penti is the harvest thanksgiving ceremony of the Manggarai people. Penti is a sign of gratitude to God the Creator (Mori Jari Dedek) and to the ancestral spirits over all the crops and the turn of the season as well. At the turn of the season between July to September every year is also done thanksgiving, penti. There is a belief of Manggarai people, if this ceremony is not implemented then God will give anger in the form of disasters that befall the Manggarai people.

\subsubsection{Order of Penti}

\subsubsection{Barong Lodok}


Lodok is a system of division of land (rice field or garden) in Manggarai in the form of cyber crebs. Lodok consists of three parts: (1) Lingko. Lingko is a lodok center planted by a tree called haju teno. Haju teno symbolizes fertility. Lingko is all the land area owned by a descendant ( $w a^{\prime} u$ ) in a village (golo). Lingko is not private but communal land belongs to all villagers. (2) Cicing.Cicing is the outer boundary of a circular garden. (3) Langang.Langang is the line of radius or barrier between the garden.

Lodok in a lingko is divided by the authority (tu'a teno), chosen from the clan leaders (tu'a-tu'a panga). The division of the circle begins with planting a teno wood by placing it into a hole that has been excavated earlier and located in the center of the circle. From the center where we planted the wood drawn the radius of the circle which then becomes the boundary among the gardens. The wood planting (tente teno) ceremony begins with a custom ritual by offering a chicken egg or a goat. The goal of the ceremony is to take a prayer and hope to God and the ancestors to give them sustenance for the land to be divided later. After prayer, the egg is placed in the place of haju teno then plugged. After the hole is covered by soil, around the teno wood will be plugged in small woods called lance koe. In this lance is tied a rope as a center to draw a boundary line or a circle of nets.

Barong means invitation, summon the spirit in the lodok center or "circle" to follow the penti. So, barong lodok is a customary rite to invite the spirit of the gardener in the center of the circle to attend the penti ceremony. Customary leader (tu'a gendang) starts the rite by doing betel meal (pandeng cepa). Cерa is a typical meal welcoming guests with a mixture of betel leaves, areca nut, and lime (saung kala, raci agu tahang). The next stage is "pa'u tuak" or watering a drink of wine tuak stored in bamboo to the ground. After that the event continued by slaughtering a pig to be dedicated to the spirits of the ancestors. Before the pig is insulted, the customary leader says "tudak ela" means to deliver the words of prayer. Сера, pa'u tuak, and the pig slaughter ceremony are performed to make the land as a place of cultivation, endowed with abundant income, and far away from catastrophe. Participants who joined the circle continued with the song called "sanda lima". After they return to the traditional house while singing some poetries telling the joy and honor of the rice that has given life.

\subsubsection{2. "Barong Wae".}

Wae means water. The participants and customary leader go to water spring called "ulung mata wae" around the village. Arriving at the place the leader say about the purpose of the arrival by hogging a rooster. This rite is done to invite the ancestral spirits as the guardians of the spring to follow the penti ceremony, so that the spring never subsided. The goal is to express gratitude to God who has created water for the lives of the villagers. After they return to the village, then they head to the compang to do barong compang.

\subsubsection{3. "Barong Compang".}

According to Deky (2016), compang is a special place composing by selected stones, on which there is a flat stone (watu lempe) and is located in the center of the village to offer offerings. After the entourage arrived at compang, the customary leader express greeting by conveying to the naga golo (naga: dragon), ancestral spirits (wura 
agu ceki), God the owner the creator (Mori Agu Ngaran, Jari Agu Dedek). The rite is to invite the spirits to follow the ceremony at the traditional house (mbaru niang). Naga golo existence is very important for Manggarai people, because the Spirit protects the villagers from fire disasters, hurricanes, or other hazards. After that, the participants return to the custom house to perform wisi loce (span mats) ceremony. The purpose is to invite the ancestral spirits to sit together and join the penti.

\subsubsection{Libur Kilo.}

Libur means to gather, kilo means family. Libur kilo is a family gathering to renew life of the whole family. The offering in rite is a chicken and a small pig. This starts with "renggas" as the opening ceremony. Renggas is singing with "sanda lima" song. The "sanda lima" has a meaning about the basic five human needs: (1) mbaru tara kaeng (residential house). (2) natas bate labar (playground). (3) wae bate teku (water springs). (4) uma bate duat (garden as a place to planting). (5) compang as a place to pray. After the ceremony teing hang each kilo or thanksgiving offerings from each family.

2.2.2.5. The peak of the ceremony is marked by the gathering of customary heads of the village, the authority who divide the lingko, the head of the family, and other villagers who are invited in the ceremony penti. After that, each family do teing hang (each family's thanksgiving offerings.

\section{RESEARCH METHODS}

\subsection{Type of Research}

The authors combine literature and field research. In the literature study, investigation of secondary data has been related to the issues studied. To collect primary data from the field, the authors use qualitative methods in which the data collected is described in the form of narrative descriptions.

\subsection{Research Subjects}

The main subjects of this research are indigenous leaders and community leaders. Selected consideration is the broad and deep knowledge contribution of the ceremony.

\subsection{Data Collection Procedures}

\subsubsection{Literature review}

Library study is done by deepening the writings of previous experts to then explore whether there are values of characters in ceremony penti and lodok division.

\subsubsection{Interview}

Interviews were conducted to explore qualitative data about penti. Open-ended questions are created to get data about character values in the ceremony.

\subsection{Data Analysis Techniques}

Techniques of analyzing research data through the following stages. 1) Grouping the data, researchers select the data from literature studies and interviews. 2) The data are 
described qualitatively to find the meaning of penti and the character values in it. 3) Analyzing the data. The data analyzed by reading and interpretation technique. 4) Drawing conclusions, the data has been processed can be used as a stepping stone to answer the formulation of research problems. 5) Presentation of data.

\section{RESULTS AND DISCUSSION}

\subsection{Research Findings}

\begin{tabular}{|c|c|c|c|c|}
\hline \multicolumn{5}{|c|}{ Meanings of “TUDAK PENTI" OR EXPRESSION OF PENTIRITE } \\
\hline No & Expression & Meaning & $\begin{array}{c}\text { Character } \\
\text { values }\end{array}$ & Meaning \\
\hline 1. & $\begin{array}{l}\text { Barong Wae: } \\
\text { Denge le meu empo, ho'o de } \\
\text { manuk kudut barong wae. } \\
\text { Wali di'a kamping ite Morin } \\
\text { agu Ngaran, ai ite poli teing } \\
\text { ami wae bate tekugm ho'o. } \\
\text { Tegi kali dami, lami agu riang } \\
\text { koe wae teku ho'o kudut } \\
\text { mboas kin wae teku, kembus } \\
\text { kin wae bate tekug'm ho'o. } \\
\text { Kudut neka koe do'ong le } \\
\text { roho agu rowes le ronco wae } \\
\text { teku ho'o. Porong inung wae } \\
\text { ho'o te guna laing latang te } \\
\text { weki agu wakar dami. Porong } \\
\text { mese bekek kali dami, gerak } \\
\text { ranga. }\end{array}$ & $\begin{array}{l}\text { Hear the ancestors, this chicken } \\
\text { is offered in this spring. Thanks } \\
\text { the Lord, for God has given us } \\
\text { water for our needs. We beg, } \\
\text { keep this drinking water! } \\
\text { Hopefully this drinking water is } \\
\text { always sufficient for our needs. } \\
\text { Maybe this water is kept away } \\
\text { from any disturbance. May it is } \\
\text { useful for the soul and body. } \\
\text { Hopefully, it always gives us } \\
\text { freshness. }\end{array}$ & Religious & $\begin{array}{l}\text { Attitudes and } \\
\text { behaviors that } \\
\text { obedient in } \\
\text { implementing } \\
\text { religious teachings } \\
\text { someone embraced. }\end{array}$ \\
\hline 2. & $\begin{array}{l}\text { Barong Compang: } \\
\text { Denge di'a lite wura, ho'o } \\
\text { manuk barong compang, ai } \\
\text { to'ong wie penti. Tegi dami, } \\
\text { kudut lengkang koe pa'ang, } \\
\text { nggalu koe ngaung, kudut } \\
\text { tadang koe darap de tanah, } \\
\text { agu kolang de leso. Tadang } \\
\text { koes raja leso, deu koes tai } \\
\text { wie, sika koes ringan, wur } \\
\text { koes rucuk, agu kando koes } \\
\text { dango. }\end{array}$ & $\begin{array}{l}\text { Dear the spirits, the village } \\
\text { guardians, this chicken we } \\
\text { dedicate to you all in this place, } \\
\text { because tonight will be held } \\
\text { penti ceremony. Please, protect } \\
\text { the whole villagers and all the } \\
\text { circumstances. Maybe we are } \\
\text { kept away from disease } \\
\text { outbreaks. Maybe we are kept } \\
\text { away from nasty maneuvers and } \\
\text { evil interference. Keep away } \\
\text { from health problems. }\end{array}$ & $\begin{array}{l}\text { Religious } \\
\text { and } \\
\text { togetherne } \\
\text { ss }\end{array}$ & $\begin{array}{l}\text { Attitudes and } \\
\text { behaviors that } \\
\text { obedient } \\
\text { implementing } \\
\text { religious teachings } \\
\text { someone embraced. }\end{array}$ \\
\hline 3. & $\begin{array}{l}\text { Libur Kilo: } \\
\text { Ho'o manuk agu ela kudut } \\
\text { libur kilo, tegi dami kali ga, } \\
\text { neka manga tuka bana kut } \\
\text { caka salang duat, neka caka } \\
\text { salang we'e, kut beka agu } \\
\text { buar, kete api one, tela galang } \\
\text { peang, kut raci kali lebo kala, } \\
\text { kudut mbaun eta mose dami } \\
\text { lemekn wa, kut malir di'a } \\
\text { tumbu wai lau, kut mese bekek }\end{array}$ & $\begin{array}{l}\text { Dear the ancestors, a chicken } \\
\text { and a pig are offered to this } \\
\text { "libur kilo" rite. Please, we } \\
\text { hope that the meal will not } \\
\text { disturb our health. Keep away } \\
\text { from interruptions when we } \\
\text { leave and leave work. May our } \\
\text { families multiply. Our life } \\
\text { needs are met and our pigs are } \\
\text { growing health. May be planted }\end{array}$ & $\begin{array}{l}\text { Religious, } \\
\text { peace- } \\
\text { loving and } \\
\text { socially } \\
\text { concerned }\end{array}$ & $\begin{array}{l}\text { Attitude and } \\
\text { obedience to follow } \\
\text { the religious } \\
\text { teachings someone } \\
\text { embraced, with } \\
\text { respect for each } \\
\text { other and protect the } \\
\text { environment }\end{array}$ \\
\hline
\end{tabular}




\begin{tabular}{|l|l|l|l|l|}
\hline gerang ranga. & $\begin{array}{l}\text { betel nut and betel leafy. May } \\
\text { experience good life and God's } \\
\text { grace abound. }\end{array}$ & \\
\hline
\end{tabular}

\subsection{Discussion}

Penti implies a great variety of meaning for Manggarai people. Penti is a form of expression or symbol of communication to God Almighty. In addition, there is a good interaction and communication between members of the community that can foster strong bonds of brotherhood. The functions of the rite for the community are as follows.

1) Ritual function, in the form of a phrase or symbol of communication to God the Almighty. The function is seen from the recitation of prayers or mantras and various offerings that must be met at the time of the event stages take place.

2) Social function, penti attract social interaction. Good interaction and communication between community members will foster strong bonds. The social contact in holding the ceremony is seen during the cooking together, until the entire preparation of the penti is held.

3) The function of aesthetics, it can be seen from the way of dress, song or music that is playing, and the beauty of the language in the prayer (tudak).

\section{CONCLUSION}

Penti is a thanksgiving ceremony that shows the character values for the Manggarai community. In addition, the ceremony shows the unique identity of Manggarai culture. Penti teaches many things: courage, sportsmanship, self-esteem, beauty, brotherhood, and religious, hard work, tough,responsibility, or discipline values. It is a form of idiom or symbol of communication to God. In addition, there is a good interaction and communication between community members in fostering strong fraternal ties. The ceremony also teaches the value of discipline and responsibility and togetherness in running a life of community. It has a religious function, aesthetic function and ritual function., and so forth. Indirectly penti implementation includes nature, humans, and God. Maybe not so many people in Indonesia who know or recognize the rite. It is not only a ceremony, but also a thanksgiving to God Almighty. Therefore, this ceremony needs to be preserved and introduced not only in Indonesia but to many people around the world.

\section{References}

1. Abut, E. Y. \& Kaleb S. Identitas Budaya Dan Maknanya Dalam Upacara Penti Orang Manggarai. Artikel. Mahasiswa Pascasarjana jurusan PBI UNS Semarang, (2013).

2. Adisti.. Penti Sebuah permainan Rakat Manggarai Flores NTT. Artikel. Di download tanggal 6 Januari 2017 dari alamat website http://sarkomkar.blogspot.co.id/2009/03/penti-sebuah-permainan-rakyat-yangsarat.html, (2015). 
3. Chyntia.. Goet Manggarai Nilai Religius Mori Jari. Artikel di download tanggal 15 Januari 2017 dari alamat website http://chyntia-abbo.blogspot.co.id/2010/09/goetmanggarai-nilai-religius-mori-jari.html. (2010)

4. Ditindb. Permainan Penti. Artikel. Di Download tanggan 13 Januari 2017 dari alamat website http://kebudayaan.kemdikbud.go.id/ditwdb/2015/12/17/permainan-penti/. (2015).

5. Deky, N. Compang Orang Manggarai (Menggulung Riuh Compang Pantai Pede). Artikel. di download tanggal 6 Januari 2017 dari alamat website http://www.nusalale.com/detailpost/compang-orang-manggarai. (2016).

6. Fajarini, U. Peranan Kearifan Lokal dalam Pendidikan Karakter. Sosio Didaktika: vol. 1. No.2. (2014).

7. Lickona, T. Pendidikan Karakter Panduan Lengkap Mendidik Siswa Menjadi Pintar Dan Baik. Bandung: Nusamedia. (2014).

8. Nucci, L. P. \& Narvaez, D. Handbook Pendidikan Moral dan Karakter. Bandung: Nusamedia. (2016).

9. Pantar, F. H. Penti Sebuah Permainan Rakyat Yang Sarat Akan Nilai-nilai Budaya. Artikel. Didownload tanggal 5 Januari 2017 dari alamat website http://sarkomkar.blogspot.co.id/2009/03/penti-sebuah-permainan-rakyat-yangsarat.html. (2009).

10. Ruyadi, Y. Model Pendidikan Karakter Berbasis Kearifan Budaya Lokal. Proceedings of the $4^{\text {th }}$ International Conference On Teacher Education; Join Conference UPI \& UPSI. Bandung. (2010).

11. Salves, G. Upacara Penti Sebagai Ekspresi Budaya. Artikel. Di download tanggal 6 Januari 2017 dari alamat website http://baimsalves.blogspot.co.id/2013/09/upacarapenti-sebagai-ekspresi-budaya.html.. (2013). 